ENTITA : Jurnal_Pendidikan_Ilmu_Pengetahuan_Sosial_dan_Ilmu-Ilmu_Sosial; Vol. 2 No.1, Juni 2020

ENTITA : Jurnal Pendidikan IImu Pengetahuan Sosial dan IImu-IImu Sosial http://ejournal.stainpamekasan.ac.id/index.php/entita

P-ISSN:2715-7555 E-ISSN:2716-1226

\title{
The Impact of Gastrodiplomacy on The Decision Making Process of Sociopreneurs
}

\author{
Anthony Nnamdi Ogbolu \\ Department of Education Economics, School of Post Graduate Studies, \\ Yogyakarta State University, Indonesia \\ anthonynnamdi.2018@student.uny.ac.id.
}

Abstract

Food undeniably is a basic necessity of man, representing our history and culture. Beyond being vital for man's survival, it is interwoven with political and economic development. In recent times, Food has continued to gain increasing prominence in the international scheme of things giving rise to what is term gastrodiplomacy. This article explores the contemporary field of gastrodiplomacy albeit limited literature, while testing the hypothesis that "There is no impact of perceived importance of gastrodiplomacy on the decision making process of sociopreneurs" at 5\% level of significance. Data was collected with the aid of an online questionnaire which was sent to a Social Media group with an estimated number of 25 sociopreneurs from within and outside the ASEAN community. 9 of 10 responses received were completed correctly and used for this study. Results from the analysis revealed that the perceived importance of gastrodiplomacy by sociopreneurs and the influence of gastrodiplomacy on their decision making process are positively correlated and statistically significant.

Keywords: gastrodiplomacy; social entrepreneurship; sociopreneu

Abstrak

Tidak dapat disangkal, makanan adalah kebutuhan dasar manusia yang mewakili sejarah dan budaya dirinya. Selain penting untuk kelangsungan hidup manusia, isu makanan juga terkait dengan perkembangan politik dan ekonomi di suatu daerah. Baru-baru ini, wacana seputar pangan semakin banyak dibicarakan di level internasional, atau yang saat ini popular dengan istilah gastrodiplomacy. Artikel ini megkaji tentang gastrodiplomacy kontemporer, terutama untuk menguji hipotesis pengaruh hubungan antara pentingnya gastrodiplomacy dengan proses pengambilan keputusan sosiopreneur pada tingkat signifikansi 5\%. Data dikumpulkan melalui bantuan kuesioner online yang dikirim ke grup media sosial, dengan prosentasi 25 sosiopreneur dari dalam dan di luar komunitas ASEAN. 9 dari 10 tanggapan yang diterima diselesaikan dengan benar dan digunakan untuk penelitian ini. Hasil dari kajian ini mendapati temuan lapangan, bahwa persepsi pentingnya gastrodiplomacy oleh sosiopreneur, serta pengaruh gastrodiplomacy pada proses pengambilan keputusan, secara keseluruhan memiliki kolerasi positif dan signifikan secara statistik.

Kata Kunci: gastrodiplomacy; kewirausahaan sosial; sosiopreneur

Received : 24 April 2020; Revised: 15 Mei 2020; Accepted: 29 Mei 2020

(c) ENTITA : Jurnal Pendidikan IImu

Pengetahuan Sosial dan IImu-IImu Sosial,

Institut Agama Islam Negeri Madura,

Indonesia 


\section{Introduction}

Food is without doubt, is a basic necessity of man and it often represents the history, traditions, and culture of a group of people (Chapple-Sokol, 2013: 161). Food is vital for human survival and is inextricably linked to political and economic development (Muldoon, 2020: 1). It has remained an important factor in diplomacy since the inception of the institution of diplomacy and the modern nation-state in the 17th century (Muldoon, 2020: 1). Humans are known not to only rely on food for survival, but also to comfort, communicate, and connect with others (Chapple-Sokol, 2013: 161).

Food has historically connected people across various cultural and geographical terrains and divides, dating back to ancient trade routes used in the transportation of goods such as coffee, sugar and spices (Suntikul, 2017: 1). The importance of food is deeply rooted in the history and tradition of diplomacy (Chapple-Sokol, 2013: 162), as it symbolizes much more than the substance, it is mixed with culture and ethnicity which remains a powerful ingredient in human and international relations (Forman \& Tara, 2014: 1). There are few aspects of humanity as richly and uniquely tied to history, culture, or geography as food (Rockower, 2014: 1). Food forms a tangible tie to every individual and nation's respective histories, traditions, and values; thereby making it a viable platform for cultural exchange (Rockower, 2014: 1);(Lipscomb, 2020: 1 ).

In recent times, there has been a surge in the relevance of food in the international scheme of things (Forman, 2016: 1). Given the increase in the movement of people globally and technology development, food is now easily shared with others across geographical divides unlike the past, giving rise to what is termed gastrodiplomacy (Lipscomb, 2020: 1). Gastrodiplomacy is aimed at creating a more oblique emotional interaction and connection through cultural diplomacy using food as a medium for cultural engagement (Rockower, 2014: 2). This cultural diplomacy tool is increasingly been used today by states to promote nation-building and nation-branding (Lipscomb, 2020: 1). Food as we know it today is 
becoming a staple of global diplomacy (Forman \& Tara, 2014: 1), creating an emotional and transcendent connection that is felt even across language barriers (Rockower, 2014: 1). However, these concepts remain a relatively understudied topic in academia.

The practical applications of gastrodiplomacy are diverse (ChappleSokol, 2013: 163). The connection between food and diplomacy has always been strong (Luša \& Jakešević, 2017: 103). This connection leads us to investigate the potential impact food as a factor influencing decision making, to determine if the power of food can be used for both social good or otherwise (Forman, 2016: 1).

This article will explore the field of gastrodiplomacy despite limited literature in this area. Also, it analyzes the influence on the decision making processes of sociopreneurs and creates a basis for future research in this field. The researcher hypothesizes that the perceived importance of gastrodiplomacy by sociopreneurs positively impacts on their decision making process.

Hypothesis: There is no impact of perceived importance of gastrodiplomacy on the decision making process of sociopreneurs.

\section{Literature Review}

Throughout history, food has played a phenomenal role in shaping the world (Pham, 2013: 6). Beyond food being a basic need for human survival (Peristiwo, 2020: 1), food was paramount in the carving of ancient trade routes and bestowing economic and political power to those who had essential food commodities like cardamom, coffee and sugar. Food indeed has a critical but understated role in our lives (Chapple-Sokol, 2013: 163), and literally paved the way for globalization (Pham, 2013: 6). In the past decade, countries such as Thailand, South Korea, and Peru have embraced the concept of gastrodiplomacy (Poon, 2014: 1).

\section{a) Definition of Gastrodiplomacy}

The term "gastrodiplomacy" was first coined by The Economist in February 2002, to describe the then new effort by the Thailand 
government to promote Thai cuisine across the globe, marking the start of State-sponsored food promotion campaigns (Lipscomb, 2020: 1).

(Rockower, 2014:), described gastrodiplomacy as "the act of winning hearts and minds through stomachs", and defined the term as the process of concerted and sustained campaigns of public relations and investment by governments and states, often in collaboration with nonstate actors, to increase the value and standing of their nation brand through food, as cited in (Suntikul, 2017: 1). While the state is the primary actor in gastrodiplomacy, private organizations, businesses, and individuals are by no means left out as they also play relevant roles (Lipscomb, 2020: 1).

\section{b) Roles of Gastrodiplomacy}

Gastrodiplomacy holds fast the bond between food and foreign policy and reveals how a country showcases its culture to the world as evident in her food (Stimson Center, 2016: 10). The strength of gastrodiplomacy is that, it is a non-verbal means of communication (Pham, 2013: 1), that inspires many individuals and communities to share their traditions and cultures, irrespective of educational background, social standing, religion or other forms of societal classifications (Stimson Center, 2016: 9). Historically this intimate connection between food and politics has emerged in diverse forms (Hopkins \& Puchala, 2016: 1).

\section{Food in Nation Branding}

Nation branding is the showcase of a nation's self-image to the world aimed at influencing its economic and political vitality. East Asian nations are known to be particularly active in this domain with Thailand considered a pioneer with the launch of The Thai government's 2002 "Global Thai Program" aimed at increasing the number of Thai restaurants abroad (Suntikul, 2017:6). Ultimately, East Asian gastrodiplomacy programs all provided an opportunity for these countries to enhance their national and cultural brands to world (Lipscomb, 2020: 1). 


\section{Food as National Security}

Beyond culture and tradition, Food has entered the security space and has remained a prominent weapon of war. Food insecurity is now being discussed as a factor that exacerbates other political, economic, and social drivers of conflict, for power is often determined by the ownership of land and food (Forman, 2016: 1) .

\section{Food as Soft Power}

Countries and individuals have used gastrodiplomacy to influence global food market and beyond, deep into international political and economic relations (Muldoon, 2020: 1). While public dialogue and conferences can lead to decision-making, it has been noted that the best negotiation and conversation often happens over meals or drinks usually far away from the purview of the public (Chapple-Sokol, 2013: 162). Soft power has been defined as the means of attracting and persuading people in order to achieve a particular outcome(s), while hard power is the ability to coerce or cajole others which could involve the use of military or economic might (Adesina, 2017: 1). In this regards, Gastrodiplomacy is not just a niche of diplomacy, because Food's intrinsic value and potential to engage "hearts and minds" all climaxing in decision making which spans beyond the diplomatic spectrum.

\section{c) Gastronomy, Socialpreneurs and Social Entrepreneurship}

Over the last two decades the term social entrepreneurship has emerged as a recognizable field in development work with youths (Karunan, 2007: 3). Social entrepreneurship is a relatively complex phenomenon, and has continued to gain more traction in recent times within and outside the research community (Ferrari, 2014: 26). The interest in social entrepreneurship began in the 1980s with the emergence of two schools of thought that aimed to invest in youths to promote positive social change and innovative solutions that are both sustainable and reproducible (Karunan, 2007: 3 ). Sociopreneurs are indeed seen as a unique genre of entrepreneurs (Ferrari, 2014: 20), who are poised to transform lives both within and outside their immediate communities. 
Although no agreeable definition of social entrepreneurship exists today, definitions from two schools of thought seem to always come in handy among researchers; The Social Enterprise School which presents social entrepreneurship as social enterprise initiatives, and The Social Innovation School which presents social entrepreneurship as the initiatives of innovators pursuing social change, aimed at alleviating a particular social problem (Karunan, 2007: 9). It is worthy of note that, the concept of social entrepreneurship should not be mistaken for traditional entrepreneurship, and of course the difference lies in their value propositions (Ferrari, 2014: 38), while their similarities rest in their basic operating principles (Swanson \& Zhang, 2012: 174).

\section{d) Roles and Characteristics of Sociopreneurs}

According to (Dees, 2001: 4); some of the societal roles that sociopreneurs play as change agents are;

1. Adopting a mission to create and sustain social value (not just private value),

2. Recognizing and relentlessly pursuing new opportunities to serve that mission,

3. Engaging in a process of continuous innovation, adaptation, and learning,

4. Acting boldly without being limited by resources currently in hand, and

5. Exhibiting a heightened sense of accountability to the constituencies served and for the outcomes created.

Social entrepreneurship and sociopreneurs are important for economic growth and development. Specifically, sociopreneurs adopt a social vision to transform the society by creating and sustaining social values (Devi, 2016: 193). Some common characteristics of sociopreneurs as noted by (Karunan, 2007: 4) includes;

1. Visionary,

2. Innovative,

3. Leadership \& dedication, 

4. Resourceful,
5. Willingness to Self-Correct,
6. Replicability and Scalability,
7. Ethical fiber, Formative Experiences,
8. Fun

\section{e) Sociopreneurs and Decision Making Process}

Sociopreneurs are innovative, highly motivated and critical thinkers (Devi, 2016: 191), who have to make various deals and decisions aimed at growing their enterprises while tackling minor and major social issues on a daily basis. Deals are generally mutually beneficial contractual relationships between the entrepreneurial ventures and the resource providers (Rostiani, Paramita, Audita, et al., 2015: 185). Decision making is the process of making a choice among alternative courses of action after careful thought $(\mathrm{OBI},:$ 93). However, decision-making is far from being thoughtful in social enterprises as it is often pervasive and highly threatened by factors both inside and outside the enterprise (Ohana, Meyer, \& Swaton, 2013: 1093).

Some researchers have argued that decision making can be an emotional event hence leaving decision maker to execute 'just good enough' decisions and not necessarily the 'best ones' as they are subjective to human elements intervening in decision making process (OBI, : 93). In a study carried out on judges, results shows that the percentage of favorable rulings drops gradually from about $65 \%$ to nearly $0 \%$ within each decision session and returns abruptly to about $65 \%$ after meal breaks (Danziger, Levav, \& Avnaim-Pesso, 2011: 6890). Another study revealed that the taste of food is also as important as the food in influencing decision (Sagioglou \& Greitemeyer, 2014: 1591). They found that the bitter taste of meal or drink evokes aggression related affect and behavioral intention towards people with or without initial provocation.

Although there exist some empirical studies on the influence of food on decision making, non seem to exist in relations to the social entrepreneurship or sociopreneurs, who are change agents making 
decisions that has continue to transform themselves and their communities at large. This has placed some limits on our understanding on sociopreneurs and their process of decision making. This study intends to explore this issue with the hope of contributing to the literature on gastrodiplomacy, and social entrepreneurship which will remain beneficial to both the academic and non academic community.

\section{Methodology}

\section{a) Sample and Procedure}

This study was administered on sociopreneurs who were participants at the 3rd ASEAN Young Sociopreneurs Program (2019). ASEAN Young Socialpreneurs Program is a biennial program organized by the Global Engagement Office, and Faculty of Social and Political Sciences of Gadjah Mada University, Indonesia aimed at bringing together young sociopreneurs from within and outside ASEAN into a two-weeks collective forum of scholars, practitioners, and professionals to improve each participants' critical understanding and social awareness of social entrepreneurship in the ever increasingly digital society (AYSPP, 2019: 1).

$A$ link that led to an online questionnaire was sent to an estimated twenty-five (25) participants through the Program's Watsapp group for a period of two days with an open invitation in which the researcher stated to uphold all best known research ethics. A total of ten (10) participants responded to the questionnaire and nine (9) completed it correctly, for a response rate of $40 \%$.

Due to the lack of available validated instrument that measures the variables of interest in this study, the researcher had to develop an instrument that measure the variables of interest from scratch. An 11-item measure was developed of which 4-items measures the perceived importance of gastrodiplomacy, and the remaining 7-items measures the level of influence gastrodiplomacy has on respondent's decision making process.

Respondents were asked use 5-point Likert scales to assess a series of statements describing their perceptions and feelings on the 
variables of interest in this study. The options range from the low to high spectrum; [Strongly Disagree/Strongly Agree] and [not at all/very much] for perceptions and feelings variables respectively.

Upon visual inspection of the data, the sample distribution appears not to be significantly different from a normal distribution. The data also reported a Skewness \& kurtosis Z-values of 1.732 which is within the normality range $(-1.96$ to +1.96$)$. Using Cronbach's alphas, the research instrument construct reliability was evaluated and the constructs were lower than 0.70. Reverse coding was used to ensure the validity of the instrument. To test the hypothesis, a regression analysis was carried out on each respondent's total score for both their perceived importance of gastrodiplomacy (IV) and the level of influence gastrodiplomacy has on their decision making process (DV).

Table 1: Demographic Information of Respondents

\begin{tabular}{|c|c|c|c|c|c|}
\hline Parameter & Freq. & Parameter & Freq. & Parameter & Freq. \\
\hline \multicolumn{6}{|l|}{ Total } \\
\hline Respondents (N) & 9 & Gender(Male) & 6 & Gender(Female) & 3 \\
\hline Age & $27(6)^{*}$ & & & & \\
\hline Education Level & & Marital Status & & Nationalities & \\
\hline Bachelors & 3 & Single & 5 & Myanmar & 1 \\
\hline Masters & 5 & Married & 4 & Congo & 1 \\
\hline Doctorate & 1 & Religion & & Indonesia & 4 \\
\hline Study Program & & Christianity & 2 & Libya & 1 \\
\hline Business oriented & 2 & Islam & 6 & Panama & 1 \\
\hline $\begin{array}{l}\text { Non-Business } \\
\text { oriented }\end{array}$ & 7 & Buddhism & 1 & Sudan & 1 \\
\hline
\end{tabular}

Note: Data is presented as frequency count. * Standard dev. in bracket

\section{Analysis and Results}

This study sets out to test the hypothesis that; There is no impact of perceived importance of gastrodiplomacy on the decision making process of social entrepreneurs. The results from the regression analysis carried out on the sample data revealed that the perceived importance of gastrodiplomacy by social entrepreneurs and the influence of gastrodiplomacy on their decision making process are positively correlated and statistically significant at alpha $5 \%$. 
Table 2: Correlation Results for Main Variables

\begin{tabular}{lllll} 
& 1 & 2 & 3 & 4 \\
\hline 1. Importance of Gastrodiplomacy & -- & & & \\
2. Influence on Decision Making & $.671^{*}$ & -- & & \\
3. Age & .374 & .083 & -- & \\
4. Education & .307 & .207 & $.766^{\star}$ & -- \\
\hline
\end{tabular}

Note: ${ }^{*} p<.05$, two-tailed

\section{Discussion}

Based on initially reviewed literature and the interest of the researcher, the objective of this study was to present and test the stated hypotheses 'There is no impact of perceived importance of gastrodiplomacy on the decision making process of sociopreneurs'. This is because traditional businesses are usually motivated by profit unlike social enterprises hence, the researcher became interested in investigating what roles basic commodities like food can play in influencing the decision making process of sociopreneurs who are believed to be social change agent and mainly interested in promoting social value which has little or nothing to do with profits instead, it involves the fulfillment of basic and long standing needs of humanity (Certo \& Miller, 2008: 267).

Findings from this study shows that sociopreneurs who appreciates the value of food or have a pleasant dining with a business associates is more likely to make a decision that is favourable to such business associates. This is evident as more that 75 percent of the respondents saw nothing wrong in allowing food to influences their decisions making process and coincided gastrodiplomacy important for the political and economic growth of any given business entity and country at large.

As anticipated by the researcher, the results of this study supports the existence of a statistically significant relationship between perceived importance of gastrodiplomacy and its ability to influence decision making process, among sociopreneurs which is in line with other findings on food's 
ability to influence people decisions (Spence, 2016: 9); (Aan het Rot, Moskowitz, Hsu, \& Young, 2015: 108); \& (Danziger et al., 2011: 6890).

Sociopreneurs should therefore ensure that they pay close attention, think through and anticipate the outcomes of their decisions especially in the context of gastrodiplomacy. While gastrodiplomacy is a relatively new field in the realm of public diplomacy (Poon, 2014: 1), more study is required to identify and elaborate upon its potential benefits or drawbacks . The America University, a private research university located in Washington, D.C, already uses the city's food culture to educate students about global affairs in a gastrodiplomacy class (Poon, 2014: 1).

\section{Conclusion}

Gastrodiplomacy encompasses a powerful medium of non-verbal communication capable of connecting all forms of people from diverse backgrounds thus serving a dynamic tool in the practice and conduct of both public and cultural diplomacy (Rockower, 2014: 4). Historically, the phrase "break the ice" originated at the time when Greeks and Romans would invite their enemies to the dining table to get to know them (Stimson Center, 2016: 9). Apparently, food when transformed through the lens of national identity can become highly influential and can be manipulated to change people's minds and hearts (Chapple-Sokol, 2013: 181).

This study set out to present and test the hypotheses that, there is no impact of the perceived importance of gastrodiplomacy by social entrepreneurs on their decision making process. The results of this study provided evidence to reject the null hypothesis, allowing the researcher to conclude that there is not only a positive relationship between perceived importance of gastrodiplomacy and its ability to influence the decision making process of social entrepreneurs but also this relationship is statistically significant at alpha $5 \%$.

This goes to show how food as a soft power is effective in influencing the decision making process of sociopreneurs.

As gastrodiplomacy and social entrepreneurship has continue to attract positive attention globally over the past decade, it is pertinent that 
more research be carried out going forward with a view to provide more and useful insights into these fields for educational institutions, policy makers, industry leaders and other relevant stakeholders. This study contributes in this regards to the scarce body of knowledge in this field that has the potential to advance the course of humanity.

\section{Limitation and Future Area of Study}

Certain limitations of this study must be brought to the fore in order to improve engagements on this study. First; the sample size used in this study was relatively small and this possibly resulted in the survey instruments reporting a less than desirable Cronbach's alphas of 0.586 , hence the findings of this study should be interpreted lightly as further studies with a larger sample size is recommended to provide more concrete results.

Intriguingly, $89 \%$ (8 out of 9) of the respondent believed that Gastrodiplomacy can influence sociopreneur's decision making processes. This was gathered from a standalone question that the researcher has included in the survey instrument. Respondents had 3 option (Yes, Indifferent, No) to respond with when presented with the statement "I believe that gastronomy can influence socio entrepreneur's decision making processes".

The researcher recommends that further studies be done to investigate the concepts of gastrodiplomacy on traditional entrepreneurs as it would be interesting to compare the impact of gastrodiplomacy on the decision making process of both sociopreneur and traditional entrepreneurs.

\section{References}

Aan het Rot, M., Moskowitz, D. S., Hsu, Z. Y., and Young, S. N. "Eating a meal is associated with elevations in agreeableness and reductions in dominance and submissiveness." Physiology \& Behavior, 144, (May 2015)103-109. https://doi.org/10.1016/j.physbeh.2015.03.014

Adesina, Olubukola S. "Projecting Nigeria'S Soft Power Through Culinary Diplomacy." The African Journal for the Psychological Study of Social Issues, 20, no. 1 (2017): 140-149. 
http://ajpssi.org/index.php/ajpssi/article/view/215\%0A

Anna Lipscomb. "Culinary Relations: Gastrodiplomacy in Thailand, South Korea, and Taiwan." The Yale Review of International Studies, (March 2019) http://yris.yira.org/essays/3080

AYSPP. (2019). ASEAN Young Socialpreneurs Program, 2019. https://ayspp.fisipol.ugm.ac.id

Chapple-Sokol, Sam. "Culinary diplomacy: Breaking Bread to Win Hearts and Minds." The Hague Journal of Diplomacy, 8, no.2 (January 2013): 161-183. https://doi.org/10.1163/1871191X-12341244

Charles Spence. "Gastrodiplomacy: Assessing the role of food in decisionmaking." Flavour, 5, no. 1, (October 2016): 1-16 https://doi.org/10.1186/s13411-016-0050-8

Christina Sagioglou, and Tobias Greitemeyer. "Bitter Taste Causes Hostility." Personality and Social Psychology Bulletin, 40, no. 12 (October 2014): 1589-1597. https://doi.org/10.1177/0146167214552792

Đana Luša and Ružica Jakešević. "The Role of Food in Diplomacy: Communicating and "Winning Hearts and Minds" Through Food." Medijske Studije, 8, no. 16, (2017): 99-118. https://doi.org/10.20901/ms.8.16.7

Gregory Dees J. "The Meaning of Social Entrepreneurship" (May 2001): 1-5. Retrieved from https://centers.fuqua.duke.edu/case/wpcontent/uploads/sites/7/2015/03/Article_Dees_MeaningofSocialEntrep reneurship_2001.pdf

Hadi Peristiwo. "Indonesian Food Industry on Halal Supply Chains." Food ScienTech Journal, 1, no. 2 (2020): 69 https://doi.org/10.33512/fsj.v1i2.6475

Johanna Mendelson Forman. "Foreign Policy in the Kitchen." EInternational Relations. (October 2016) https://www.eir.info/2016/10/05/foreign-policy-in-the-kitchen

Johanna Mendelson Forman and Tara Sonenshine. "Food and Foreign Policy: A Diplomatic Cuisine." The Globalist, (March 2014) https://www.theglobalist.com/food-foreign-policy-diplomatic-cuisine/

James Nwoye Obi. "Decision-Making Strategies" In C.P. Maduabum (Ed.) Contemporary Issues on Management in Organizations: A Book of Readings Ch. 6, p.93. Retrieved from http://eprints.covenantuniversity.edu.ng/10021/1/DECISION-MAKING 


\section{STRATEGIES.pdf}

James P. Muldoon Jr. "Food Diplomacy." International Encyclopedia of the Social Sciences. (2020) https://www.encyclopedia.com/socialsciences/applied-and-social-sciences-magazines/food-diplomacy

Lee A. Swanson and David D. Zhang. "Social Entrepreneurship." Entrepreneurship - Gender, Geographies and Social Context, (March 2012) https://doi.org/10.5772/36056

Linda Poon. "Gastrodiplomacy : Cooking Up A Tasty Lesson On War And Peace." NPR: The Salt. (March 2014) https://www.npr.org/sections/thesalt/2014/03/24/291980375/gastrodipl omacy-cooking-up-a-tasty-lesson-on-war-and-peace\%0A

Marc Ohana, Maryline Meyer and Sophie Swaton. "Decision-Making in Social Enterprises." Nonprofit and Voluntary Sector Quarterly, 42, no. 6 (2013): 1092-1110. https://doi.org/10.1177/0899764012451368

Mary Jo A. Pham. "Food as Communication: A Case Study of South Korea's Gastrodiplomacy." Journal of International Service, 22, no. 1 (Spring 2013): 1-22. www.amercian.edu/SIS/JIS

Paul Rockower. "The State of Gastrodiplomacy". BIDD. (March 2014) https://www.bidd.org.rs/the-state-of-gastrodiplomacy

Raymond F. Hopkins and Donald J. Puchala. "Perspectives on the International Relations of Food." International Organization, The Global Political Economy of Food, 32, no 3, (Summer, 1978): 581616. https://www.jstor.org/stable/2706327

Rokhima Rostiani, Widya Paramita, Handini Audita, Risa Virgosita, Teguh Budiarto, and Boyke R. Purnomo. "Understanding Social Enterprises in Indonesia." Journal of Indonesian Economy and Business, 29, no. 2 (2014):, 183-191. https://doi.org/10.22146/jieb.v29i2.6356

Sebastian Ferrari. "Social Entrepreneurship: Business Models and Earned Income Strategies." Theses, MODUL Vienna University, (June 2014) Retrieved from https://www.modul.ac.at/uploads/files/Theses/Bachelor/Bachelor_The sis_Sebastian_Ferrari.pdf

Seema Devi. "Social Entrepreneurship: Challenges in Way To Rise." International Journal of Research - Granthaalayah, 4, no. 9 (September 2016) https://doi.org/10.5281/zenodo.556415

Shai Danziger, Jonathan Levav, and Liora Avnaim-Pesso. "Extraneous factors in judicial decisions". Proceedings of the National Academy of 
Sciences, 108, no. 17 (April 2011): 6889-6892.

https://doi.org/10.1073/pnas.1018033108

Stimson Center. "The Conflict Cuisine Project. Is The Kitchen The New Venue Of Foreign Policy?: Ideas On Food As A Tool For Diplomacy, Building Peace And Cultural Awareness." (2016) Retrieved from https://www.jstor.org/stable/resrep10919

Trevis Certo S. and Toyah Miller . "Social entrepreneurship: Key issues and concepts." Business Horizons. 151, no 4, (July-August 2008): 267-271. https://doi.org/10.1016/j.bushor.2008.02.009

Victor P. Karunan. "Adolescents and civil engagement: social entrepreneurship and young people." United Nations Children's Fund, (October 2007) Retrieved from https://www.unicef.org/Learning_Series_3_Social_Entrepreneurship_ 24dec2007.pdf\%0A

Wantanee Suntikul. "Gastrodiplomacy in tourism." Current Issues in Tourism, 22, no. 9, (August 2017): 1076-1094. https://doi.org/10.1080/13683500.2017.1363723 
Anthony Nnamdi Ogbolu 